\title{
A Vertically Integrated Portfolio Process to Foster Entrepreneurial Mindset Within an Undergraduate Biomedical Engineering Curriculum
}

\section{Dr. Cristi L. Bell-Huff, Georgia Institute of Technology}

Cristi L. Bell-Huff, PhD is a Lecturer in the Wallace H. Coulter Department of Biomedical Engineering at Georgia Tech and Emory University where she is involved in teaching and engineering education innovation and research. In addition to her PhD in Chemical Engineering, she also has an MA in Educational Studies. She has industrial experience in pharmaceutical product and process development as well as teaching experience at the secondary and post-secondary levels.

\section{Todd M. Fernandez, Georgia Institute of Technology}

Todd is a lecturer in the Wallace H. Coulter Department of Biomedical Engineering at Georgia Institute of Technology. His research interests are about engineering students beliefs about knowledge and their formation through the engineering education experience.

\section{Dr. Kali Lynn Morgan}

\section{Dr. Paul Benkeser, Georgia Institute of Technology}

Paul J. Benkeser is a professor and Senior Associate Chair in the Wallace H. Coulter Department of Biomedical Engineering at Georgia Tech and Emory University. He is past chair of ASEE BED and has served a number of roles for IEEE EMBS.

\section{Prof. Joseph M LeDoux, Georgia Institute of Technology}

Joe Le Doux is the Associate Chair for Undergraduate Learning and Experience in the Department of Biomedical Engineering at Georgia Tech and Emory University. Dr. Le Doux research efforts focus on professional and interpersonal practices that promote inclusion, belonging and state authenticity, sociocognitive aspects of interactive learning environments, and story-driven learning. 


\title{
A Vertically Integrated Portfolio Process to Foster Entrepreneurial Mindset Within an Undergraduate Biomedical Engineering Curriculum
}

\begin{abstract}
The Wallace H. Coulter Department of Biomedical Engineering at Georgia Tech is currently making an intentional effort to vertically integrate entrepreneurial minded learning within the undergraduate curriculum. With funding from the Kern Family Foundation, the goals of this work are not only to better equip students to meet the demands of the modern marketplace but also to empower students to tell the story of their growth into entrepreneurially minded engineers. In order to tell this story, students engage in a portfolio process grounded in evidence and reflection. The structure of this story-centric curricular framework consists of a first-year launcher course where foundational topics such as design thinking, reflection, folio thinking, and entrepreneurial mindset are introduced. At the other end of the framework is a unique course called The Art of Telling Your Story. In this upper level course, students learn to tell their unique stories of their experiences and entrepreneurial mindset growth culminating in an ePortfolio. In between these two curricular bookends, students are involved in their core biomedical engineering classes. Five of these core courses are designated as gateway courses. In gateway courses, students complete signature assignments specifically created to foster entrepreneurial mindset and critical reflection. These signature assignments are also designed to produce meaningful artifacts and experiences that may later be used as part of students' stories and portfolios. In this paper, we describe the details of the structure and implementation of this vertically integrated curricular framework and present evidence of entrepreneurial mindset growth within freshmen and upper level students' ePortfolios.
\end{abstract}

\section{Introduction}

In order to foster entrepreneurial mindset development throughout the undergraduate experience, Wallace H. Coulter Department of Biomedical Engineering at Georgia Tech has created a vertically integrated portfolio process centered around entrepreneurial mindset, reflection, and stories. The goal of this work is to empower students to tell the story of their growth into entrepreneurially minded engineers. Through connecting, reflecting upon, and constructing their unique stories, students begin to see themselves as engineers who have developed and will continue to develop an entrepreneurial mindset to create value for others. The purpose of this paper is to present an overview of the structure and implementation of this unique vertically integrated, story-centric portfolio process. 


\section{Background}

The Wallace H. Coulter Department of Biomedical Engineering at Georgia Tech is part of the Kern Entrepreneurial Engineering Network (KEEN). KEEN is a collaboration of universities across the United States dedicated to instilling an entrepreneurial mindset in their undergraduate engineering and technology students. KEEN, through the Kern Family Foundation, provides financial and developmental resources to participating institutions to enable the growth of curricular, co-curricular, and extra-curricular activities that enhance the entrepreneurial mindset in their students. Specifically, KEEN emphasizes the development of engineers that exhibit an "entrepreneurial mindset coupled with engineering thought and action expressed through collaboration and communication and founded on character." [1] In support of this, KEEN has created a framework of student outcomes and example behaviors that may be used to inform the design of programs seeking to develop an entrepreneurial mindset. These outcomes and behaviors are centered around what KEEN calls The $3 C$ 's - curiosity, connections, and creating value. Specific example behaviors of curiosity, connections, and creating value as described by the KEEN framework may be seen in Figure 1 [1] and it is through this lens that we have incorporated entrepreneurially minded learning into our undergraduate curriculum. Fostering an entrepreneurial mindset characterized by dispositional curiosity, integrative learning (connections), and creating value is a primary goal of the vertically integrated undergraduate program described in this paper.

\begin{tabular}{|l|l|}
\hline Curiosity & $\begin{array}{l}\text { - Demonstrate constant curiosity about our changing world } \\
\text { - Explore a contrarian view of accepted solutions }\end{array}$ \\
\hline Connections & $\begin{array}{l}\text { - Integrate information from many sources to gain insight } \\
\text { Creating Value }\end{array}$ \\
& - Assess and manage risk \\
\hline
\end{tabular}

Figure 1: KEEN Entrepreneurial Mindset Framework Example Behaviors of Curiosity, Connections, and Creating Value [1]

An important part of helping our students recognize and tell the story of their entrepreneurial mindset growth is scaffolding their ability to make meaning of their experiences. Reflection is a powerful tool toward this end [2]. Reflection is typically defined as consciously looking at and thinking about experiences, actions, feelings, and responses, and analyzing them in order to learn [3]. Turns et al. describes reflection as "an intentional form of thinking where a person revisits an experience with a specific meaning making lens" [2]. The original recognition of the importance of reflective thinking on learning is usually credited to Dewey as part of his myriad contributions 
to education in general. Dewey focused on making experiences meaningful and connecting experiences and future actions [4]. Kolb further underscored the importance of reflection in his Experiential Learning Model which situates reflective observation as the link between concrete experience and abstract conceptualization in learning [5]. Indeed, Schon asserts that the distinguishing factor between expert and novice practitioners is the ability to reflect on their practice, especially in the face of complex problems [6]. Despite the importance of reflection in learning, reflective thought has not been historically emphasized in engineering education. More recently, reflection has received more attention in engineering education scholarship and Turns et al. provide an excellent review of these efforts and the importance of reflection in engineering education [2]. Recognizing the significance of reflection both in making meaning of experiences and in preparing students to deal with the ambiguous problems they will face as practicing engineers certainly necessitated an emphasis on reflection throughout the vertically integrated portfolio process described in this paper.

While an emphasis on reflective thinking is critical for mindset growth, this is not sufficient for achieving the goal of empowering students to tell the story of their growth into entrepreneurially minded engineers. Building on the foundation of reflection as a key skill, to achieve our program goals we are leveraging the power of story-driven learning, that is the intellectual work of reflective, evidence-based story creation and curation. The premise of our program is that through the work of connecting and reflecting on their prior experiences, analyzing and interpreting evidence from those experiences, and building their own unique narratives based on these experiences, students will be able to tell the story of their entrepreneurial mindset growth. Students will also begin to see themselves as engineers who have and will continue to develop an entrepreneurial mindset to create value for others.

Stories are central to how people think and feel about themselves, their identity, and their mindset. Stories are important in human cognition and interaction [7]. They help people share and build culture and knowledge that are vital to individual and group development by contextualizing knowledge and providing interpretation of events. Storytelling is a "uniquely human activity that draws critically upon the ability to model social situations and events" and is one of the earliest ways that people learn [8]. Narratives improve information processing, recall, and engagement in learning and there is even evidence that the narrative thinking mode may be the brain's default mode [7]. Inside and outside the classroom, engaging with narratives has been shown to be a powerful tool for shifting mindsets [9], knowledge, attitudes, and behaviors [10]. Because of their reflective nature, stories lend themselves to being an effective way of making sense of experiences. Social psychology research shows that "although people can and do think about experiences in context-free propositional terms...more often than not (stories) come to mind when people think about themselves and others" or when they interpret events and experiences [11]. Based on the evidence of the power of stories in affecting mindset, we have 
integrated the process of creating, telling, and listening to stories as a pedagogical approach within our engineering curriculum through the vertically integrated portfolio process described in this paper.

\section{Overview and Implementation}

As mentioned, the goal of our program is to prepare students to tell the story of their growth into entrepreneurially minded engineers by engaging them in a story-centric portfolio process grounded in evidence and reflection. Figure 2 shows the overall structure of our curricular framework.

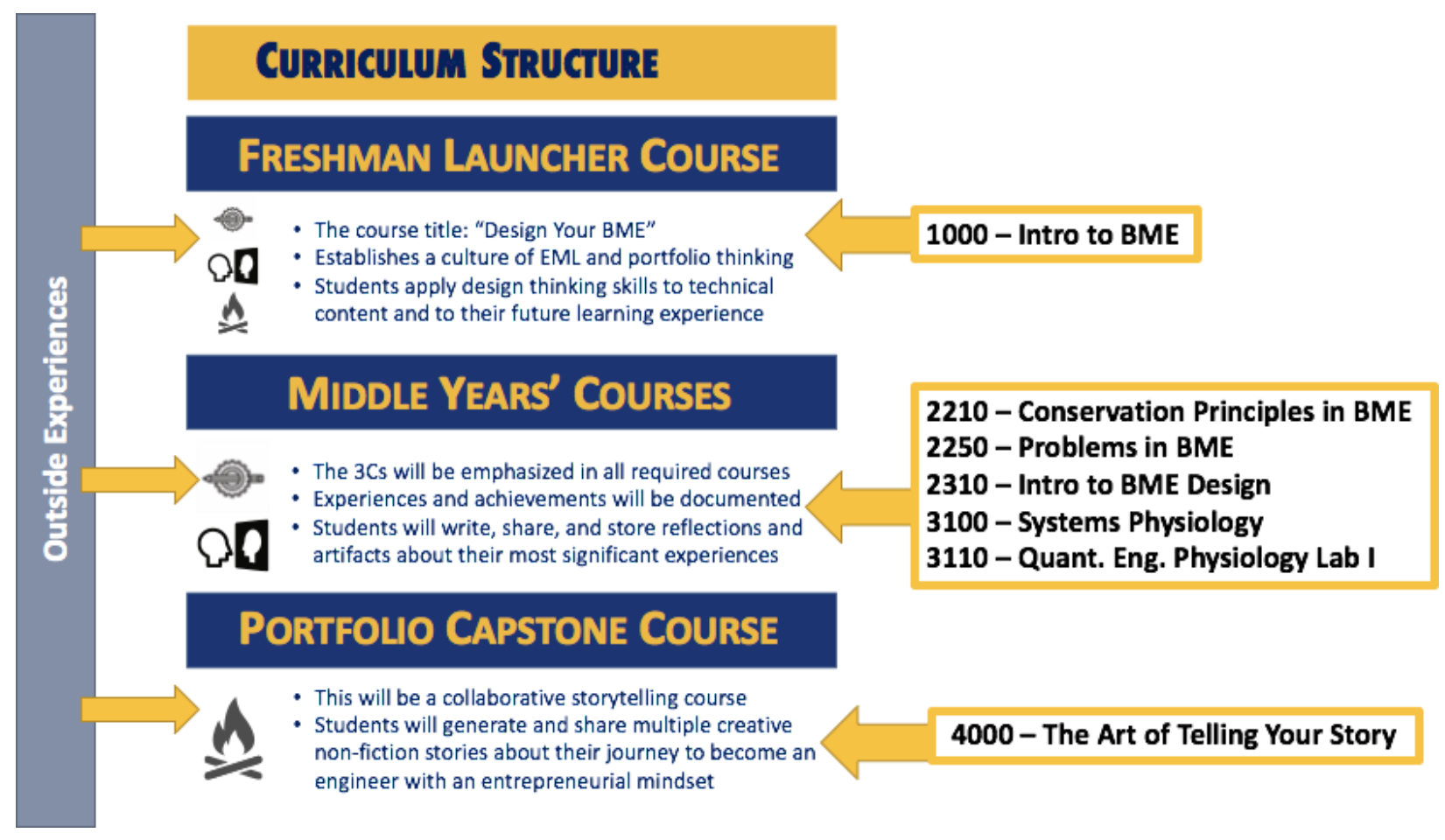

Figure 2: Vertically Integrated Program Overview

This framework begins with a first-year launcher course called BMED1000 Introduction to Biomedical Engineering. In this class, foundational topics such as design thinking, reflection, ePortfolios, and entrepreneurial mindset are introduced. Indeed, an overarching goal of this course is to establish a culture of folio thinking. Penny Light et al. [12] refer to folio thinking as the reflective practice of portfolio creation. This process of learning encourages students to "integrate discrete learning experiences, enhance their self-understanding, promote taking responsibility for their own learning, and support them in developing an intellectual identity" [12]. Students are also introduced to the biomedical engineering field and encouraged early on to become part of the BME community at Georgia Tech. Students complete nine focused reflection 
assignments as part of our work toward teaching reflection as an engineering skill and scaffolding the students ability to reach the levels of reflection/critical reflection described by Kember et al. [13]. Additionally, reflection is incorporated into the design projects and discussions throughout the course. BMED1000 was designed and piloted during the 2018-19 academic year and is now running at full scale as a required course for entering biomedical engineering majors. At the end of BMED1000, students create a learning portfolio using Google sites that tells their story of initial entrepreneurial mindset growth over the course of their first semester at Georgia Tech. They also share their portfolios with faculty, peers, and upper level students from BMED4000 (described below) at an ePortfolio showcase event at the end of the semester.

At the other end of the curricular framework is a unique culminating course called BMED4000 The Art of Telling Your Story. In this upper level course, students learn to make connections between their experiences throughout their time at Georgia Tech and reflect on these experiences through the lens of an entrepreneurial mindset. While BMED1000 focuses on folio thinking as a means of developing entrepreneurial mindset, BMED4000 enhances mindset growth through story-driven learning. Students create and curate the unique stories of their experiences and entrepreneurial mindset growth over the course of their college experience. This culminates in a collection of stories curated into a portfolio format using Google sites. Given the unique nature, we piloted this course three times as a 5-week, special topics storytelling course both on the Georgia Tech campus and as part of our study abroad program in Galway, Ireland. During Fall 2019, we developed BMED4000 into a semester long format that included additional entrepreneurially minded learning (EML) content and activities designed to equip students to better tell the story of their entrepreneurial mindset growth. As in BMED1000, students showcase their work at an end of the semester portfolio showcase event attended by faculty, peers, and first year students from BMED1000 (described above). We are now teaching BMED4000 in the new semester-long format. Students entering the BME program in Fall 2020 and beyond will be required to take BMED4000, in addition to BMED1000.

In between the two curricular bookends of BMED1000 and BMED4000, students are involved in their core biomedical engineering classes. Five of these core courses are designated as gateway courses. In gateway courses, students complete a variety of signature assignments specifically created to foster entrepreneurial mindset and reflection. These signature assignments are also designed to produce meaningful experiences and artifacts that will be used later as part of the students' story-driven learning experiences and ePortfolios. The Association of American Colleges and Universities (AAC\&U) describes a signature assignment as one that should require students to synthesize, analyze, and apply cumulative knowledge and skills, may also follow a theme across curricular and co-curricular experiences, and often must include specific components such as reflective writing. AAC\&U also states, "A distinctive feature of signature 
assignments is the way programs integrate them across the educational pathway to help students demonstrate their growth, make connections across the curriculum and co-curriculum, and apply their knowledge to real world problems" [14].

We use the above characteristics as our guide to create signature assignments to carry the theme of entrepreneurial mindset and reflection throughout our undergraduate curriculum. We also design these signature assignments to help students make connections between outside experiences and content within our gateway courses while intentionally incorporating social pedagogy as a powerful learning approach. Table 1 briefly summarizes the kinds of signature assignments instructional teams are deploying for each gateway course and how the various desired components are incorporated. We have also included our Academic Office workshops as part of our Gateway Course Matrix in Table 1 since these diverse workshops align well with the types of entrepreneurial mindset and reflective activities we want students to engage in throughout the curriculum. We use our Gateway Course Matrix to track progress and alignment in our gateway courses as well as to ensure that students are experiencing entrepreneurial mindset and reflection in a variety of ways throughout the curriculum.

Table 1: Gateway Course Matrix

\begin{tabular}{|c|c|c|c|c|c|}
\hline Gateway Course & Signature Assignment Description & $\begin{array}{l}\text { Potential artifacts for portfolio } \\
\text { from signature assignment }\end{array}$ & & $\begin{array}{l}\text { Topic for outside experiences } \\
\text { pulled into the signature } \\
\text { assignment or course }\end{array}$ & $\begin{array}{l}\text { Social pedagogy incorporated into } \\
\text { signature assignment }\end{array}$ \\
\hline $1000-$ Intro to BME & Creating the BMED 1000 ePortfolio & $\begin{array}{l}\text { - Reflections } \\
\text { - BME Insider Activity } \\
\text { - Two design projects }\end{array}$ & • & Practical competence & $\begin{array}{l}\text { BMED } 1000 \text { showcase with } \\
\text { feedback from showcase } \\
\text { attendees }\end{array}$ \\
\hline $\begin{array}{l}2210 \text { - Conservation } \\
\text { Principles in BME }\end{array}$ & $\begin{array}{l}\text { Raise student awareness of how } \\
\text { model based reasoning can create } \\
\text { value for others }\end{array}$ & $\begin{array}{ll}\text { - } & \text { Conceptual model } \\
\text { - } & \text { Math model/diagram } \\
\text { Reflections }\end{array}$ & - & $\begin{array}{l}\text { Interpersonal experiences- } \\
\text { connected to through the } \\
\text { reflections }\end{array}$ & $\begin{array}{l}\text { - Jigsaw activities for feedback from } \\
\text { others }\end{array}$ \\
\hline $\begin{array}{l}\text { 2250 - Problems in } \\
\text { BME }\end{array}$ & $\begin{array}{l}\text { A series of reflections based on EM } \\
\text { at each phase with a culminating } \\
\text { reflection as a pitch to a target } \\
\text { audience }\end{array}$ & $\begin{array}{ll}\text { - Reflections } \\
\text { - Final pitch created }\end{array}$ & - & Team experiences & $\begin{array}{l}\text { - Peer feedback on final reflection } \\
\text { pitches } \\
\text { - Teamwork feed back discussions }\end{array}$ \\
\hline $\begin{array}{l}2310 \text { - Intro to BME } \\
\text { Design }\end{array}$ & $\begin{array}{l}\text { Teams create a pitch video to } \\
\text { communicate opportunity identified, } \\
\text { solution, and value proposition }\end{array}$ & $\begin{array}{ll}\text { - } & \text { Video } \\
\text { - } & \text { Team website (extra credit) }\end{array}$ & • & $\begin{array}{l}\text { Persistence and learn through } \\
\text { failure - connected through } \\
\text { DEEM chart and reflection }\end{array}$ & $\begin{array}{l}\text { - Share videos } \\
\text { Design feedback from peers and } \\
\text { users }\end{array}$ \\
\hline $\begin{array}{l}\text { 3100- Systems } \\
\text { Physiology }\end{array}$ & $\begin{array}{l}\text { New England Journal of Medicine } \\
\text { case study analysis }\end{array}$ & $\begin{array}{l}\text { - Reflections at the end of each } \\
\text { case study including EM }\end{array}$ & - & Career path & $\begin{array}{l}\text { Guided discussions about the case } \\
\text { studies }\end{array}$ \\
\hline $\begin{array}{l}3110-\text { Quantitative } \\
\text { Eng. Physiology Lab }\end{array}$ & $\begin{array}{l}\text { Learning from difference working on } \\
\text { teams to create value }\end{array}$ & - Reflections & • & $\begin{array}{l}\text { Learning from differences } \\
\text { (connected to form a team to } \\
\text { create the most value in the } \\
\text { future) }\end{array}$ & $\begin{array}{l}\text { - Sharing their experiences across } \\
\text { groups }\end{array}$ \\
\hline $\begin{array}{c}\text { Academic Office } \\
\text { Workshops/Activities }\end{array}$ & $\begin{array}{l}\text { Various topics depending on } \\
\text { workshop, internship reflections, } \\
\text { research experience reflections }\end{array}$ & $\begin{array}{l}\text { Reflections or other products of } \\
\text { workshops \& experiences }\end{array}$ & • & Professional development & $\begin{array}{l}\text { Practice at workshops, } \\
\text { presentations with feedback }\end{array}$ \\
\hline $\begin{array}{l}4000-\text { The Art of } \\
\text { Telling Your Story }\end{array}$ & $\begin{array}{l}\text { Creating the E-Mindset growth } \\
\text { ePortfolio }\end{array}$ & $\begin{array}{l}\text { - Anything from their library of } \\
\text { artifacts and stories }\end{array}$ & • & SUMMATIVE & - Story Showcase \\
\hline
\end{tabular}

Creating gateway courses with signature assignments that drive our vertically integrated program involves curriculum development as well as faculty and staff development related to entrepreneurial mindset, reflection, stories, and course design. Ten faculty members are involved in developing, implementing, and continuously improving our gateway courses. These course 
instructors along with a postdoctoral fellow with expertise in higher education, two faculty trained in curriculum development, and an academic office staff member form our Course Implementation Team. This team meets every two weeks. The purpose of these meetings includes aligning vision and goals, sharing progress, and providing each other with constructive feedback. To assist in this process we have created a set of Design Sheets to guide our team's course and signature assignment development, provide formative feedback, and help us evaluate signature assignment alignment with our overall goals.

Another key aspect of our curricular development in gateway courses is the creation of student-faculty partnerships. Each year, 4-8 biomedical engineering students are recruited based on previous course experience, academic performance, and expressed interest in entrepreneurially minded learning and course development. These student partners form a core team of Course Implementation Assistants (CIA). Instructional teams for each of our gateway courses are then matched with one or more CIA student partners and charged with continual development of signature assignments in their courses. We have found these student-faculty partnerships to be both a significantly positive, meaningful experience and an important way for us to foster entrepreneurial mindset, empathy, and respect within both students and faculty [15].

During the design and implementation of our vertically integrated program, our faculty development focus has been on gateway course development. However, we have also engaged in other faculty development activities related to our goals. For example, faculty development activities to support the upper level, story-driven learning course (BMED 4000) have been important since this is such a unique course. We have held in-house workshops to give faculty a first hand experience as a student in that course. We have also organized additional workshops on reflections and ePortfolios with recognized experts in these areas as facilitators.

\section{Initial Analysis of Impact on Entrepreneurial Mindset Growth}

Currently, we are in our first year of full implementation of our vertically integrated program at Georgia Tech. While we have not had a full cohort of students experience the entire curriculum sequence, we have made a first attempt to understand the effectiveness of our program to empower students to tell the story of their growth as entrepreneurially minded engineers, we sought to understand 1) how well students' reflective abilities were being developed in the BMED1000 class, and 2) how students conceptualize and demonstrate entrepreneurial mindset at either end of the curricular framework so far.

While in BMED1000, students complete nine focused reflection assignments as part of our work toward fostering folio thinking, teaching reflection as an engineering skill, and scaffolding the students ability to reach the levels of reflection or critical reflection described by Kember et al. 
[13]. In Kember's framework, reflection may be quantified according to four levels - habitual action, understanding, reflection, and critical reflection. The higher levels of reflection/critical reflection are characterized by students applying theory to practical situations, providing personal insights beyond theory, and effectively communicating a change in perspective [13]. To assess how students' reflective abilities developed in our first-year course, a team consisting of two instructors and six teaching assistants analyzed each written reflection assignment submitted by students enrolled in BMED1000 during Fall 2019. The team characterized the levels of reflection according to the Kember framework. We then compared the levels of reflection achieved by students in the initial reflection assignment to that of the final reflection assignment of the semester as shown in Table 2. At the beginning of the semester, $66 \%$ of the students showed a level of reflection or critical reflection within the initial assignment. By the final assignment, this number rose to $89 \%$ of the students writing at a level of reflection or critical reflection. The increase in the number of students reaching higher levels of reflection is an important indicator of the impact and future success of our program since reflection is a foundational skill students need to connect and make meaning of their experiences and ultimately, to tell the story of their growth as entrepreneurially minded engineers.

Table 2: Number of Students at Each Level of Reflective Ability in BMED1000

\begin{tabular}{|l|c|c|c|c|}
\hline & & Level of Reflection & & \\
\hline & Habitual Action & Understanding & Reflection & Critical Reflection \\
\hline Initial Reflection & 8 & 37 & 46 & 41 \\
\hline Final Reflection & 3 & 14 & 49 & 95 \\
\hline
\end{tabular}

To understand how students conceptualize and demonstrate entrepreneurial mindset at either end of the curricular framework, we analyzed ePortfolios produced by students at the end of BMED 1000 Introduction to Biomedical Engineering and BMED 4000 The Art of Telling Your Story during the Fall semester of 2019. For BMED1000, we analyzed portfolios from across the course sections through the lens of an entrepreneurial mindset as characterized by the KEEN framework of curiosity, connections, and creating value. We looked for common themes and misconceptions as well as good examples of students' displaying an understanding of their entrepreneurial mindset growth over the course of their first semester at Georgia Tech.

Purposeful sampling across all sections $(\mathrm{n}=30)$ and thematic analysis of BMED1000 portfolios revealed students gained a good understanding of design thinking, including the importance of empathy and understanding stakeholder needs in order to create value. Students also displayed good understanding of the concepts related to entrepreneurial mindset. Some exemplary quotes 
from student portfolios illustrating an accurate understanding of entrepreneurial mindset as described by the KEEN framework are shown in Table 3.

Table 3: Illustrative Excerpts from BMED1000 Portfolios

\begin{tabular}{|c|c|}
\hline $\begin{array}{l}\frac{\text { Component of }}{\text { Entrepreneurial }} \\
\text { Mindset }\end{array}$ & Excerpts from BMED1000 Portfolios \\
\hline Curiosity & $\begin{array}{l}\text { 1. The initial burst of curiosity led me to learning how exactly } \\
\text { to use the 3-D modeling software, Solidworks, as well } \\
\text { learning how to convert a file to be able to be printed by the } \\
\text { 3-D printers here on campus. The end result of my curiosity } \\
\text { is a 3-D printed piece of floor tile that fits into the whole like } \\
\text { a glove... } \\
\text { 2. Diving into this project felt daunting at first. However, I was } \\
\text { interested enough in learning how to work a sander, how to } \\
\text { properly spray paint, how to use a 3D printer, that my } \\
\text { curiosity helped to push through the doubt and uncertainty. }\end{array}$ \\
\hline Connections & $\begin{array}{l}\text { 1. I developed my entrepreneurial mindset by making subtle } \\
\text { comparisons between some of the most contrasting ideas. } \\
\text { 2. We then made connections between the information we } \\
\text { received in both interviews in order to gain a better } \\
\text { understanding of the needs of new faculty. The Campus Map } \\
\text { Project gave me experience in making connections between } \\
\text { disparate pieces of information in order to find an optimal } \\
\text { solution. }\end{array}$ \\
\hline Creating Value & $\begin{array}{l}\text { 1. Creating value was an essential component of this hack } \\
\text { because I was challenged to find an unexpected opportunity } \\
\text { to help students graduate from college. Additionally, I } \\
\text { persisted in finding a solution through failure by rewriting } \\
\text { code and learning from online help desks when my code } \\
\text { resulted in error. } \\
\text { 2. I realized the most important step in creating value is } \\
\text { empathizing with the customer to create what they want, not } \\
\text { what you think they need. }\end{array}$ \\
\hline
\end{tabular}


Within the BMED1000 portfolios, there were also some misconceptions related to an entrepreneurial mindset as described by the KEEN framework. For example, some students had difficulty conceptualizing curiosity as described within the KEEN framework. These students tended to relate this concept to the idea of being willing to try new things or of having broad interests rather than exhibiting behaviors such as investigating "our changing world" or "exploring contrarian views" [1]. Also, students often illustrated their development of connections with evidence of networking, meeting people, and making friends. The idea of connections as part of an entrepreneurial mindset within the KEEN framework relates to "integrating information from many sources to gain insight" or "assessing and managing risk" rather than to making social connections [1]. Finally, a small number of students continued to see the concept of creating value as purely a financial activity rather than considering this concept more broadly as was emphasized throughout the semester in BMED1000. Some students also chose artifacts and reflections that focused more on using an entrepreneurial mindset to create value for themselves as part of their own personal development rather than creating value for others.

Since we are only now in our first year of implementation of our vertically integrated portfolio process, students who are required to take BMED1000 as freshmen have not yet progressed far enough through the BME curriculum to be enrolled in BMED4000. Therefore, we are not able to fully assess the impact on entrepreneurial mindset growth by direct comparison of student portfolios in both BMED1000 and BMED4000 yet. However, we have been implementing our signature assignments in gateway courses and have implemented the first full semester version of BMED4000 over the past year. Thus, we performed thematic analysis of students' BMED4000 portfolios $(n=24)$ in order to gain insight into how these upper level students conceptualize and demonstrate development of their entrepreneurial mindset in story-centric portfolios toward the end of their college experience.

In general, portfolios of students who experienced the creating and curating of unique, personal stories in BMED4000 showed richer, more specific discussions of mindset growth than those in BMED1000. BMED4000 students also focused their stories more clearly on transformation and change in perspective while choosing more meaningful artifacts as evidence for their growth. BMED4000 students displayed a more mature conceptualization of each of the KEEN aspects of an entrepreneurial mindset. For example, BMED4000 students tended to correctly relate curiosity to the concept of investigating ideas that might create value as opposed to simply having broad interests or being willing to try new things. Also, none of the upper level students conceptualized connections as networking or making social connections as was seen in the freshmen portfolios. Some exemplary quotes from BMED4000 student portfolios illustrating understanding of entrepreneurial mindset according to the KEEN framework are shown in Table 4. 
Table 4: Illustrative Excerpts from BMED4000 Portfolios

\begin{tabular}{|c|c|}
\hline $\begin{array}{l}\frac{\text { Component of }}{\text { Entrepreneurial }} \\
\underline{\text { Mindset }}\end{array}$ & Excerpts from BMED4000 Portfolios \\
\hline Curiosity & $\begin{array}{l}\text { 1. This day, I didn't want to just daydream. I had to know if } \\
\text { there actually was a better solution. I had to know if there } \\
\text { actually was a way to create a better solution. I began } \\
\text { researching. I started out looking at texts discussing the } \\
\text { anatomical relationships and moved onto osteopathic } \\
\text { approaches. It was intriguing... } \\
\text { 2. I've been enamored by the intersection between the clinic } \\
\text { and my engineering coursework at Georgia Tech: research in } \\
\text { the fields of immunoengineering and synthetic biology. Like } \\
\text { a T cell receptor drawn to its specific antigen, I am } \\
\text { captivated by the immune system, an intricate microscopic } \\
\text { world within our bodies powerful enough to fight virtually } \\
\text { any presented disease. What if we could leverage these same } \\
\text { endogenous mechanisms for the treatment of refractory } \\
\text { malignancies? }\end{array}$ \\
\hline Connections & $\begin{array}{l}\text { 1. Then it hit me. We needed to increase the maximum possible } \\
\text { deformation for our retractors. We needed to transform them } \\
\text { from the rigid metal structures to a more flexible device with } \\
\text { a little "give." That insight was only possible from } \\
\text { biomechanics, which I was taking that semester. In } \\
\text { combination with what I had learned in my material science } \\
\text { coursework, I suggested that we use an acrylic material. } \\
\text { Instead of modifying the geometry, we attacked the material } \\
\text { properties! } \\
\text { 2. After identifying which problem my group and I were going } \\
\text { to solve, we started interviewing children with asthma, their } \\
\text { parents, physicians, nurses and more to really understand the } \\
\text { problem from as many lenses as possible. The more we dug } \\
\text { into the problem, the more solutions we could think of } \\
\text {...After weeks and weeks of testing prototypes..., we landed } \\
\text { on a design that integrated } 2 \text { mechanical solutions for } 2 \\
\text { different problems we noticed with asthmatic children. }\end{array}$ \\
\hline
\end{tabular}




\begin{tabular}{|c|c|}
\hline Creating Value & $\begin{array}{l}\text { 1. Though this was an incredibly simple solution, the } \\
\text { translation of subjective criteria into indisputable standards } \\
\text { ultimately helped to reduce the high scrap rates without } \\
\text { sacrificing product quality. } \\
\text { 2. From the poignancy of that first witnessed heart attack, I } \\
\text { have concluded that becoming a physician offers a chance to } \\
\text { live out my many values through a singular profession. I } \\
\text { strive to practice medicine in order to optimize the } \\
\text { technology and public health equation; I aspire to help lift } \\
\text { healthcare beyond the bounds of the hospital. For me, } \\
\text { becoming a doctor represents the fusion of my engineering } \\
\text { toolkit with my beliefs in healthcare access, the fusion of } \\
\text { community advocacy with my passion for patient-focused } \\
\text { care. It is connecting at eye-level with those in every } \\
\text { condition, recognizing that as humans we share the melody } \\
\text { of a heartbeat. }\end{array}$ \\
\hline
\end{tabular}

\section{Future Work}

Developing and implementing a vertically integrated portfolio process throughout the undergraduate BME curriculum has the potential to significantly impact entrepreneurial mindset growth within our students. The design of the curricular framework described in this paper has involved course development, faculty development, and project management activities over the course of the past two years. During the next phase of our work, we will engage in continuous improvement efforts for our current series of gateway courses and signature assignments as well as create signature assignments for additional core BME courses. We will also continue faculty development activities related to incorporating entrepreneurial mindset, reflections, and stories into BME courses. Another important part of our future work includes expanding the impact of our program to other engineering departments within Georgia Tech and other universities both inside and outside the KEEN network. We are currently working on developing more rigorous assessment tools for evaluating the impact of our program on the growth of students' entrepreneurial mindset. We will be able to use these tools once the entire program is running at full scale allowing us to understand students' entrepreneurial mindset growth by making direct comparisons between student ePortfolios at the beginning of our program in BMED1000 to those at the end of our program in BMED4000. By making direct comparisons between BMED1000 and BMED4000 portfolios we will be able to explore the affordances of both folio thinking and story-driven learning on the promotion of entrepreneurial mindset since we are experimenting with each of these approaches in BMED1000 and BMED4000, respectively. 


\section{Acknowledgements}

The authors would like to thank the Kern Family Foundation for their generous financial and developmental support.

\section{References}

[1] “KEEN Engineering Unleashed." [Online]. Available: https://engineeringunleashed.com/mindset-matters/framework.aspx.

[2] J. Turns, B. Sattler, K. Yasuhara, J. Borgford-Parnell, and C. Atman, "Integrating Reflection into Engineering Education," in 121st Annual Conference \& Exposition, Indianapolis, IN, 2014, vol. Paper ID \#9230.

[3] "Learning to learn, Reflecting backwards, reflecting forwards," The Open University. [Online]. Available: www.open.edu/openlearn/.

[4] J. Dewey, How we think. Mineola, N.Y: Dover Publications, 1997.

[5] D. A. Kolb, Experiential learning: experience as the source of learning and development. Englewood Cliffs, N.J: Prentice-Hall, 1984.

[6] D. A. Schön, The reflective practitioner: how professionals think in action. New York: Basic Books, 1983.

[7] S. Martinez-Conde et al., "The Storytelling Brain: How Neuroscience Stories Help Bridge the Gap between Research and Society," J. Neurosci., vol. 39, no. 42, pp. 8285-8290, Oct. 2019, doi: 10.1523/JNEUROSCI.1180-19.2019.

[8] P. Deane, S. Somasundaran, R. R. Lawless, H. Persky, and C. Appel, "The Key Practice, Building and Sharing Stories and Social Understandings: The Intrinsic Value of Narrative," ETS Res. Rep. Ser., vol. 2019, no. 1, pp. 1-78, Dec. 2019, doi: 10.1002/ets2.12266.

[9] R. Delgado, "Storytelling for Oppositionists and Others: A Plea for Narrative," Mich. Law Rev., vol. 87, no. 8, p. 2411, Aug. 1989, doi: 10.2307/1289308.

[10] S. T. Murphy, L. B. Frank, J. S. Chatterjee, and L. Baezconde-Garbanati, "Narrative versus Nonnarrative: The Role of Identification, Transportation, and Emotion in Reducing Health Disparities: Narrative vs. Nonnarrative," J. Commun., vol. 63, no. 1, pp. 116-137, Feb. 2013, doi: 10.1111/jcom.12007.

[11] R. F. Baumeister and L. S. Newman, "How Stories Make Sense of Personal Experiences: Motives that Shape Autobiographical Narratives," Pers. Soc. Psychol. Bull., vol. 20, no. 6, pp. 676-690, Dec. 1994, doi: 10.1177/0146167294206006.

[12] T. Penny Light, H. L. Chen, and J. C. Ittelson, Documenting learning with ePortfolios: a guide for college instructors, 1st ed. San Francisco: Jossey-Bass, 2012.

[13] D. Kember, J. McKay, K. Sinclair, and F. K. Y. Wong, "A four-category scheme for coding and assessing the level of reflection in written work," Assess. Eval. High. Educ., vol. 33, no. 4, pp. 369-379, Aug. 2008, doi: 10.1080/02602930701293355.

[14] "Association of American Colleges and Universities." [Online]. Available: https://www.aacu.org/.

[15] C. Bell-Huff, K. Morgan, and J. Le Doux, "Work In Progress: Faculty Partnering With Students in Biomedical Engineering Undergraduate Curriculum Development," in 126th Annual Conference and Exposition, 2019, vol. Paper ID \#24697. 